\title{
Physico-chemical and sensorial variation in camel milk produced at different zones of Sindh, Pakistan
}

\author{
Muhammad Haroon Baloch ${ }^{1 *}$, Atta Hussain Shah ${ }^{2}$, Zaheer Ahmed \\ Nizamani $^{3}$, Muhammad Naeem Rajput ${ }^{1}$ and Habibullah Magsi ${ }^{4}$ \\ 1. Department of Livestock Management, Sindh Agriculture University, Tandojam-Pakistan \\ 2. Animal Products Technology, Sindh Agriculture University, Tandojam-Pakistan \\ 3. Veterinary Pathology, Sindh Agriculture University, Tandojam-Pakistan \\ 4. Agriculture Economics, Sindh Agriculture University, Tandojam-Pakistan \\ *Corresponding author's email: mharoonbaloch@gmail.com
}

Citation

Muhammad Haroon Baloch, Atta Hussain Shah, Zaheer Ahmed Nizamani, Muhammad Naeem Rajput and HabibullahMagsi. Physico-chemical and sensorial variation in camel milk produced at different zones of Sindh, Pakistan. Pure and Applied Biology. Vol. 7, Issue 2, pp625-634. http://dx.doi.org/10.19045/bspab.2018.70078

\begin{tabular}{llll}
\hline \hline Received: 05/04/2018 & Revised: 07/05/2018 & Accepted: 08/05/2018 & Online First: 12/05/2018 \\
\hline \hline
\end{tabular}

\section{Abstract}

Despite camels are best milk yielders in Sindh, Pakistan; their milk is rarely consumed in significant extent probably due to unawareness of its food value, use and/or consumers' acceptability. Present study merits, evaluating the variability in the physico-chemical properties and sensory profile of camel milk at irrigated plains (IP), sandy desert (SD) and coastal mangroves (CM) zones of Sindh, Pakistan. Experiment was randomized with complete block design, where 90 camel milk samples from each of the three studied zones were examined. Most of the characteristics were recorded significantly different. $\mathrm{pH}$ values and viscosity at $\mathrm{SD}$ and $\mathrm{CM}$ were found non-significant but these were significantly $(\mathrm{P}<0.05)$ different at IP $(6.50$ and $1.17 \mathrm{cP}$, respectively). Titratable acidity observed considerably high at CM $(0.178 \%)$ followed by SD $(0.169 \%)$ and IP $(0.165 \%)$. Specific gravity, conductivity $(\mathrm{mS} / \mathrm{cm})$ and refractive index $(1.032,5.04$ and 1.3452, respectively) were abundant at IP compared to CM and SD. Moisture content recorded at SD (89.50\%) was high followed by CM (89.21\%) and IP (88.81\%). Fat content was comparatively abundant at IP $(3.19 \%)$ than at CM and SD. Total protein, casein, non-casein nitrogen and whey protein at IP and CM found non-significant, but significantly high from that of noted at SD $(3.00,2.07,0.115$ and $0.54 \%$, respectively). Lactose and solids not fat contents at SD and CM noted non-significant, but appeared significantly low from that of IP (4.03 and 8.01\%, respectively). Camel milk at IP perceived markedly better score for appearance/color (8.95 over 10), odor/aroma (3.36 over 5), taste/flavor (31.26 over 45), body/texture (3.64 over 5) and overall acceptability (6.32 over 9) followed by camel milk at CM and SD. Though, sensory profile of camel milk versus buffalo milk was not comparable yet score perceived for all the sensory attributes were under acceptable limits and might open the door for its utilization at Sindh, Pakistan.

Keywords: Camel milk; Chemical; Physical; Sensorial; Variation

\section{Introduction}

Camel (Camelus dromedarius) is a unique animal though survives and reproduces under harsh climatic conditions for longer periods without drinking, and can replenish the loss in a very short time compared to other kinds 
of livestock [1]. This unique adaptability makes this specie ideal for exploitation under the arid, semi-arid, mountainous and desert areas of the world, and therefore, contributes significantly to the food security of the nomadic pastoral households. Camels are generally raised under sedentary, transhumant and nomadic production systems in different camel habitats of Pakistan, and are well known and famous for milk production with an average milk yield of 4179 liters per year [2], probably the best milk yielder in the world. Despite this uniqueness, camel milk has not been utilized to significant extent probably due to unawareness of the use and the market value of camel milk or because of its saltish taste and high acidic nature $[3,4]$. However, it is much more nutritious than that of cow milk because it is low in fat content and rich in protein, minerals and vitamins especially in vitamin C [5]. In Pakistan, 0.862 million tons of camel milk is produced annually [6] and primarily consumed locally in raw state. Despite the fact that camel milk is produced in appreciable quantity, its composition varies greatly in several studies [7-9]. Very limited studies are so far reported in relation to physico-chemical and sensorial characteristics of camel milk in Pakistan; hence, present investigation was conducted in this regard at different vicinities of camel habitat zones of Sindh, Pakistan.

\section{Materials and methods}

Experiment was randomized with complete block design where three camel habitat zones of Sindh, Pakistan were kept as treatment variables, while in each zone three districts were included as block variable. In each block, a total of 30 camel milk samples ( 90 samples from each treatment variable) were randomly collected into clean sterile bottles, and transported under refrigeration to the laboratory of the Department of Animal Products Technology, Faculty of Animal Husbandry and Veterinary Sciences, Sindh

Agriculture University Tandojam and stored under refrigerator $\left(4-8^{\circ} \mathrm{C}\right)$ till analysis. All the samples were examined for physicochemical and sensory characteristics. Further, during evaluation of sensory profile of camel milk, buffalo milk was kept as control for comparison purpose.

\section{Analysis of physical variables}

Titrable acidity, specificgravity, viscosity and conductivity were analyzed according to the standard methods of [10].

\section{pH values}

The intensity of hydrogen ions in camel milk was determined using $\mathrm{pH}$ meter (Hanna Instruments, Model No.H-8417). The electrode and temperature probe was dipped in milk sample, and the values were noted from the screen of $\mathrm{pH}$ meter.

Refractive indexThe refractive index of camel milk samples was recorded using Refractometer (Model RX-5000 $\alpha$, ATAGO. Co. LTD, Tokyo, Japan).

\section{Examination of chemical variables}

Moisture, ash, non-casein nitrogen and casein contents and the total protein content wereexamined using standard methods [10, 11] respectively.

\section{Fat content}

Fat content of camel milk was determined by Gerber method [12]. Milk sample (11ml) was mixed with $90 \%$ sulfuric acid $(10 \mathrm{ml})$ and amyl alcohol $(1 \mathrm{ml})$ in butyrometer and closed with rubber cork. The butyrometer was placed in a Gerber centrifuge machine (Funk Gerber, Model No. 12105, Germany) and centrifuged for $5 \mathrm{~min}$ at $1100 \mathrm{rpm}$. The fat percent was noted on the butyrometer scale.

\section{Whey protein}

Firstly, milk sample was treated in similar fashion as for casein [10]. Thereafter, filtrate (20ml) was analyzed for $\mathrm{N} \%$ age. The result obtained was multiplied with 6.38 to express whey protein $\%$.

\section{NPN content}


NPN content was determined according to the method [13]. Sample (10ml) was taken into a pre-weighed conical flask and reweighed (nearest $0.1 \mathrm{mg}$ ). Trichloro acetic acid (TCA) solution (40ml) was added to the flask, and contents with flask weighed. Solution was swirled to mix and left to stand approximately $5 \mathrm{~min}$ to allow the precipitate settle. Contents of the flask were filtered through filter paper and filtrate was collected in the clean, dry conical flask. Mixed filtrate (20ml) was then analyzed for $\mathrm{N} \%$ age. The result obtained was multiplied by 6.38 to calculate protein equivalent of non-protein nitrogen content.

\section{Lactose and solids not fat contents (SNF)}

Both variables were computed by difference methods. In case of lactose content, the sum of percent of protein, fat and ash contents were subtracted from the percent of total solids content, while SNF content was calculated by deducting the percent of fat content from the percent of total solids content [10].

\section{Evaluation of sensory variables}

Sensory characteristics of camel milk were evaluated according to the method reported by [14]. A panel of six judges was selected, and they were first familiarized with sensory profile of milk. Thereafter, camel milk from each block variable was offered one by one for evaluation using sensory protocol. The score was rated on hedonic scale of 10 for appearance/color, 5 each for odor/aroma and body/texture, and 45 for taste/flavor. Overall acceptability score was rated on nine-point hedonic scale where one for "disliked extremely" and nine for "liked extremely" [15].

\section{Statistical analysis}

The data so obtained were processed using computerized statistical package i.e. Student Edition of Statistix (SXW), Version 8.1 (Copyright 2005, Analytical Software, USA). Statistical procedure of analysis of variance (AOV) under Linear Models was applied, and in case of significant differences appeared, the treatment variables were further differentiated using least significant difference (LSD) test [16].

\section{Results and discussion}

\section{Physical characteristics of camel milk}

The physical characteristics like $\mathrm{pH}$, acidity, conductivity, refractive index, specific gravity and viscosity of camel milk varied zone to zone (Table 1). The $\mathrm{H}^{+}$intensity in milk of camel raised at coastal mangroves $(6.48 \mathrm{pH})$ recorded slightly high from camel milk produced at sandy desert $(6.49 \mathrm{pH})$ zone, but found statistically non-significant $(\mathrm{P}>0.05)$. However, camel milk at irrigated zone $(6.50 \mathrm{pH})$ noted significantly high $(\mathrm{P}<0.05)$ in $\mathrm{H}^{+}$from milk of camel reared at both former zones. These results were further confirmed through titratable acidity test, whereby acidity percent in camel milk appeared significantly high $(\mathrm{P}<0.05)$ at coastal mangroves $(0.178 \%)$ compared to milk of camel habitat at sandy desert $(0.169 \%)$ and irrigated plains $(0.165 \%)$. The percent of acidity in milk of camel at both of later zones noted non-significant $(\mathrm{P}>0.05)$. It is noteworthy that intensity of $\mathrm{H}^{+}$in camel examined under current study found high than that of reported studies $[17,18]$, who examined the $\mathrm{pH}$ values 6.63 and $6.64 \pm 0.02$ $(0.15 \pm 0.01 \%$ acidity), respectively. However, in another study camel milk recorded more intense in $\mathrm{H}^{+}(5.97 \pm 0.03 \mathrm{pH})$ [19] contrast to that of present study. Specific gravity of camel milk varied significantly $(\mathrm{P}<0.05)$ at camel habitat zones of Sindh province. It was comparatively high at irrigated plains (1.032) followed by coastal mangroves (1.030) and sandy desert (1.029). It is intended to say that specific gravity of milk had positive correlation with solids not fat content [20]. This correlation was apparently confirmed in the present investigation as trend in variation is specific gravity (Table 1) and SNF content (Table 2) in camel milk found in similar fashion at all 
three camel habitat zones of Sindh, Pakistan. Moreover, the results of specific gravity in all three zones were not in accordance with findings of [21], i.e. 1.014 to 1.017 and [22] i.e. average 1.015 , while agreed with results of [23], who reviewed the average specific gravity of camel milk as 1.031. Viscosity of camel milk (Table 1) recorded significantly $(\mathrm{P}<0.05)$ high in milk of camel reared at irrigated plains $(1.07767 \mathrm{cP})$ contrast to that of at coastal mangroves $(1.68569 \mathrm{cP})$ and sandy deserts $(1.6500 \mathrm{cP})$. It is noteworthy that viscosity of milk of camel reared at irrigated plains found relatively similar, and habitat at coastal mangroves or sandy desert the low from that of reported by [24]. Moreover, it is expressed that incorporation of viscosity in milk might be due to friction of fat and dispersed protein, and increase in these components might increase the viscosity [25] and this probably happened in the present study, where viscosity of camel milk appeared with similar trend of fat and total protein in camel milk (Table 2).
Conductivity of camel milk varied area to area (Table 1). It recorded high at irrigated plains $(5.0389 \mathrm{mS} / \mathrm{cm})$ and low at sandy desert $(4.6971 \mathrm{mS} / \mathrm{cm})$; while at coastal mangroves, it was at intermediate level $(4.8622 \mathrm{mS} / \mathrm{cm})$. It has been reported that the conductivity is directly correlated with level of mineral $^{+}$(ions) [25]. This probably happened in the present investigation where trend of conductivity appeared with similar fashion as for mineral contents recorded in all three zones of Sindh, Pakistan (Table 2). Refractive index in camel milk (Table 1) recorded considerably $(\mathrm{P}<0.05)$ high at irrigated plains (1.3452) compared to that of observed at coastal mangroves (1.3450) and sandy desert (1.3448). It has been stated that refractive index increases proportionally as a function of dissolved compounds [25] and in the current study though found higher in milk of camel at irrigated zones (Table 2) resulting high refractive index in milk of camel contrast to that of milk of camel at other camel habitat zones of Sindh, Pakistan.

Table 1. Physical characteristics of camel milk at different habitat of Sindh, Pakistan

\begin{tabular}{|c|c|c|c|c|c|}
\hline \multirow[b]{2}{*}{ Physical variables } & \multicolumn{3}{|c|}{ Camel milk (Vicinity) } & \multirow[b]{2}{*}{$\begin{array}{l}\text { LSD } \\
(\mathbf{0 . 0 5})\end{array}$} & \multirow[b]{2}{*}{$\mathrm{SE} \pm$} \\
\hline & $\begin{array}{l}\text { Irrigated } \\
\text { Plains }\end{array}$ & $\begin{array}{l}\text { Sandy } \\
\text { Desert }\end{array}$ & $\begin{array}{c}\text { Coastal } \\
\text { Mangroves }\end{array}$ & & \\
\hline $\mathrm{pH}$ values & $6.50^{\mathrm{a}}$ & $6.49^{\mathrm{b}}$ & $6.48^{\mathrm{b}}$ & 0.01 & 0.005 \\
\hline Titratable acidity (\%) & $0.165^{b}$ & $0.169^{\mathrm{b}}$ & $0.178^{\mathrm{a}}$ & 0.006 & 0.003 \\
\hline Specific gravity & $1.0319^{\mathrm{a}}$ & $1.0285^{\mathrm{c}}$ & $1.0301^{\mathrm{b}}$ & 0.001 & 0.0006 \\
\hline Viscosity (cP) & $1.7767^{\mathrm{a}}$ & $1.6500^{\mathrm{b}}$ & $1.6856^{\mathrm{b}}$ & 0.0632 & .0321 \\
\hline Conductivity (mS/cm) & $5.0389^{\mathrm{a}}$ & $4.6971^{\mathrm{c}}$ & $4.8622^{\mathrm{b}}$ & 0.1266 & 0.0643 \\
\hline Refractive Index & $1.3452^{\mathrm{a}}$ & $1.3448^{\mathrm{c}}$ & $1.3450^{\mathrm{b}}$ & 0.0001 & 0.00006 \\
\hline
\end{tabular}

Means with different letters in same row varied significantly from one another

\section{Chemical characteristics of camel milk}

Results mentioned in (Table 2) indicate an appreciable variation in composition of camel milk between irrigated plains, sandy desert and coastal mangroves of Sindh province, Pakistan. This is probably due to ecology of camel browse vegetation though are quite different from one another at these areas. No doubt, the influence of some other factors like inherited capabilities of camel, seasonal variation, availability of drinking water, type of water and vegetation, stage of lactation, age etc were also reported in different studies $[17,21,26,30]$.

Fluctuations in moisture content in camel milk were recorded at different camel habitat 
zones of Sindh province. Camel milk found considerably $(\mathrm{P}<0.305)$ low in moisture content at irrigated plains $(88.81 \%)$ and high at sandy desert $(89.50 \%)$, while it was at intermediate level at coastal mangroves $(89.21 \%)$. In fact, the consequence of these results might support the choice; type and availability of camel browse vegetation in these areas though have significant influence on chemical composition of camel milk [2631]. Nevertheless, the variation in moisture content observed in the present study found within a range of reported studies [32-34]. Fat content in milk of camel (Table 2) at sandy desert $(2.85 \%)$ recorded comparatively low from those reared at other zones like coastal mangroves $(3.01 \%)$ and irrigated plains $(3.19 \%)$. It is noteworthy that fat content in milk has direct/indirect correlation with total solids content. The trend of fat concentration observed in the present study of course confirmed this correlation. Moreover, variation in fat concentration in camel milk could be attributed with water intakes and/or nature of vegetation eaten by camels could have significant effect on the extensive variation in this component of camel milk. Nevertheless, the variation in fat content from 4.3 to $1.1 \%$ in milk of camel has been reported in different studies [21, 29, 34]. Protein contents in milk of camel (Table 2) raised at irrigated plains $(3.17 \%)$ and coastal mangroves $(3.16 \%)$ recorded relatively similar $(\mathrm{P}>0.05)$, and significantly high $(\mathrm{P}<0.05)$ from that of milk of camel habitat at sandy desert $(3.00 \%)$. Similarly, the protein fractions like casein, whey protein, noncasein nitrogen examined in present showed similar trend of concentration in camel milk. However, among protein content the casein content recorded abundant followed by whey protein and non-casein nitrogen, while nonprotein nitrogen content was observed with non-significant variation $(\mathrm{P}>0.05)$ among all three zones of current study. It is noteworthy that protein content of feed and water intake had direct effect on protein quantity and/or quality of milk [26]. Thus, it could be incurred from the current results that availability and type of camel browse vegetations at former two camel habitat zones might be rich in protein source than that of latter zone, i.e., sandy desert. Nevertheless concentration range of protein observed in present study found in line with that of reported by $[21,35,36]$. Lactose content of camel milk (Table 2) at sandy desert (3.85\%) and coastal mangroves $(3.82 \%)$ appeared statistically nonsignificant $\quad(\mathrm{P}>0.05)$ but significantly $(\mathrm{P}<0.05)$ low from that of noted at irrigated plains (4.02\%). It could be argued that camel usually grazed on halophilic plants, for instance, Artiplex, Acacia, etc. [37] and other camel browse vegetation though might be rich in carbohydrates at irrigated plains other than former two zones, and resulted the above said trend in lactose content in camel milk. Nevertheless, the concentration of lactose content in camel milk observed in the current study found in a range of reported percent of $[21,37,38]$. Regardless, the ash content of camel milk (Table 2) recorded high in milk of camel reared at irrigated plains $(0.79 \%)$ from that of at coastal mangroves $(0.76 \%)$ and sandy deserts $(0.74 \%)$, the differences existed statistically non-significant $(\mathrm{P}>0.05)$ among them. Nevertheless, significant fluctuation in ash content in camel milk was reported [21, 37, $39,40]$, and reasons had been attributed with differences in type and availability of water and camel browse vegetation. No significant $(\mathrm{P}>0.05)$ variation was recorded in solids not fat content in camel milk (Table 2) at sandy desert (7.65\%) and coastal mangroves $(7.78 \%)$. However, in both of the above camel habitat zones, the concentration of SNF contents in camel milk varied significantly $(\mathrm{P}<0.05)$ from milk of camel raised at irrigated plains $(8.01 \%)$. In fact, the variation in SNF content (range 5.56 to 
$8.29 \%$ ) in camel milk was also reported in a study conducted by [21] and though supports the current study.

\section{Sensory characteristics of camel milk}

In contrast to buffalo milk, sensory profile (appearance/color, odor/aroma, taste/flavor and body/texture) of camel milk rated comparatively $(\mathrm{P}<0.05)$ low, and found less acceptable (Table 3). It is noteworthy that sensory attributes of camel milk vary with ruminant species because of their physicochemical properties [40] and buffalo milk reported dominant in these properties compared to camel milk $[41,42]$. Color/appearance score rated for milk of camel at irrigated plains (8.95) recorded significantly high $(\mathrm{P}<0.05)$ followed by coastal mangroves (8.64) and sandy desert (8.40) over total score of 10 . However, the score for color/appearance of camel milk at above three areas did not reach at the score rated for similar attributes of buffalo milk (9.28) and found significantly $(\mathrm{P}<0.05)$ low (Table 3). Although, camel milk perceived low score for color/appearance from that of buffalo milk, it was ranked at highly acceptable limit. In fact the color/appearance of milk correlates with concentration of fat and casein contents present in such milk [30] and this correlation has been confirmed in the present study. The score for color/appearance of camel milk rated in sandy area (Table 3) noted in similar trend as for fat and/or casein content observed in the current study (Table 2 ), and buffalo milk reported high in fat content than that of camel milk [42] where score was in similar manner. Odor/aroma score rated for camel milk at three camel habitat zones of Sindh province (irrigated plains, sandy deserts and coastal mangroves) found under acceptable limit. However, it varied considerably area to area in the present study. Camel milk at irrigated plains perceived better $(\mathrm{P}<0.05)$ score $(3.36)$ for odor/aroma over total score of 5 (Table 3) compared to coastal mangroves (3.24) and sandy desert (3.15). Nevertheless, score for odor/aroma perceived by camel milk at sandy desert area did not compete with that of received by buffalo milk as control (4.47). It could be argued that odor/aroma in milk might be enhanced from feed eaten, type of water intake and surrounding environment, and these conditions vary at camel habitat zones of Sindh province. These conditions reflected the dominancy on odor/aroma attributes of camel milk accordingly. Taste/flavor is of course assumed to be important attribute of sensory space map of milk. The score perceived for this attribute found in similar trend as for color/appearance and/or odor/aroma whereby control milk (buffalo) rated significantly $(\mathrm{P}<0.05)$ better score compared to camel milk at three zones of Sindh province (Table 3). Nevertheless, among camel milk taste/flavor score rated comparatively $(\mathrm{P}<0.05)$ high at irrigated plains (31.26) followed by coastal mangroves (30.17) and sandy desert (29.34) over total score of 45. These scores probably ranked under acceptable limit. This trend of score for taste/flavor rated for camel milk might correlate with trend of fat content of camel milk observed in the current study (Table 2). In fact, the fraction of fat and protein in milk might enhance the taste/flavor of milk [20]. Moreover, type of fodder and availability of drinking water were reported to cause changes in taste /flavor in camel milk [30]. In the current study, the influence of above two factors on taste/flavor attributes of camel milk found dominant whereby camel browse vegetation and availability of type of water vary area to area. Variation in milk flavor might also occur due to animal metabolism and interaction between animal, environmental conditions and feed [43]. Body/texture score of camel milk (Table 3 ) at irrigated plains rates significantly $(\mathrm{P}<0.05)$ better (3.64) than that of coastal mangroves (3.51) and sandy desert (3.41) area of Sindh province. These scores for body/texture for 
camel milk in these areas although found not comparable with that of received for buffalo milk, but are at acceptable limit. However, the variation in score for body/texture might correlate with availability of camel browse vegetation and drinking water [30]. Overall acceptability score also rated in similar manner as for other sensory attributes for camel milk in the current study (Table 3). Moreover, buffalo milk found more acceptable compared to that of camel milk, though ruminant species had significant influence on accepted profile because of its chemical properties [40].

Table 2. Comparison of chemical characteristics (\%) of camel milk at different habitat of Sindh, Pakistan

\begin{tabular}{|c|c|c|c|c|c|}
\hline \multirow{2}{*}{$\begin{array}{c}\text { Chemical characteristics } \\
(\%)\end{array}$} & \multicolumn{3}{|c|}{ Camel milk (Vicinity) } & \multirow{2}{*}{$\begin{array}{c}\text { LSD } \\
(\mathbf{0 . 0 5})\end{array}$} & \multirow[b]{2}{*}{$\mathrm{SE} \pm$} \\
\hline & $\begin{array}{l}\text { Irrigated } \\
\text { Plains }\end{array}$ & $\begin{array}{l}\text { Sandy } \\
\text { Desert }\end{array}$ & $\begin{array}{c}\text { Coastal } \\
\text { Mangroves }\end{array}$ & & \\
\hline Moisture content & $88.81^{\mathrm{c}}$ & $89.50^{\mathrm{a}}$ & $89.21^{\mathrm{b}}$ & 0.211 & 0.107 \\
\hline Fat content & $3.19^{\mathrm{a}}$ & $2.85^{\mathrm{c}}$ & $3.01^{\mathrm{b}}$ & 0.127 & 0.064 \\
\hline Protein content & $3.17^{\mathrm{a}}$ & $3.00^{\mathrm{b}}$ & $3.16^{\mathrm{a}}$ & 0.080 & 0.041 \\
\hline Casein & $2.19^{\mathrm{a}}$ & $2.07^{\mathrm{b}}$ & $2.18^{\mathrm{a}}$ & 0.059 & 0.030 \\
\hline Non-casein nitrogen & $0.123^{\mathrm{a}}$ & $0.115^{\mathrm{b}}$ & $0.121^{\mathrm{a}}$ & 0.004 & 0.002 \\
\hline Non-protein nitrogen & 0.031 & 0.030 & 0.032 & 0.002 & 0.0009 \\
\hline Whey protein & $0.59^{\mathrm{a}}$ & $0.54^{\mathrm{b}}$ & $0.57^{\mathrm{a}}$ & 0.025 & 0.013 \\
\hline Lactose content & $4.02^{\mathrm{a}}$ & $3.85^{\mathrm{b}}$ & $3.82^{\mathrm{b}}$ & 0.104 & 0.053 \\
\hline Ash content & 0.79 & 0.74 & 0.76 & 0.026 & 0.013 \\
\hline Solids not fat content & $8.01^{\mathrm{a}}$ & $7.65^{\mathrm{b}}$ & $7.78^{\mathrm{b}}$ & 0.133 & 0.068 \\
\hline
\end{tabular}

Means with different letters in same row varied significantly from one another

Table 3. Sensory characteristics (Score) of camel milk at different habitat of Sindh, Pakistan

\begin{tabular}{|c|c|c|c|c|c|c|}
\hline \multirow[b]{2}{*}{ Sensory attributes } & \multirow{2}{*}{$\begin{array}{c}\text { Buffalo } \\
\text { milk } \\
\text { (Control) }\end{array}$} & \multicolumn{3}{|c|}{ Camel milk (Vicinity) } & \multirow[b]{2}{*}{$\begin{array}{c}\text { LSD } \\
(\mathbf{0 . 0 5})\end{array}$} & \multirow[b]{2}{*}{ SE \pm} \\
\hline & & $\begin{array}{l}\text { Irrigated } \\
\text { Plains }\end{array}$ & $\begin{array}{l}\text { Sandy } \\
\text { Desert }\end{array}$ & $\begin{array}{c}\text { Coastal } \\
\text { Mangroves }\end{array}$ & & \\
\hline $\begin{array}{l}\text { Colour/appearance } \\
\text { (max } 10 \text { score) }\end{array}$ & $9.28^{\mathrm{a}}$ & $8.95^{\mathrm{b}}$ & $8.40^{\mathrm{d}}$ & $8.64^{c}$ & 0.157 & 0.080 \\
\hline $\begin{array}{l}\text { Odor/aroma } \\
\text { (max } 5 \text { score) }\end{array}$ & $4.47^{\mathrm{a}}$ & $3.36^{\mathrm{b}}$ & $3.15^{\mathrm{d}}$ & $3.24^{\mathrm{c}}$ & 0.067 & 0.034 \\
\hline $\begin{array}{c}\text { Taste/flavor } \\
(\max 45 \text { score })\end{array}$ & $39.43^{\mathrm{a}}$ & $31.26^{\mathrm{b}}$ & $29.34^{\mathrm{d}}$ & $30.17^{\mathrm{c}}$ & 0.603 & 0.307 \\
\hline $\begin{array}{l}\text { Body/texture } \\
\text { (max } 5 \text { score) }\end{array}$ & $4.42^{\mathrm{a}}$ & $3.64^{\mathrm{b}}$ & $3.41^{\mathrm{d}}$ & $3.51^{\mathrm{c}}$ & 0.069 & 0.035 \\
\hline $\begin{array}{l}\text { Overall acceptability } \\
\text { (max } 9 \text { score })\end{array}$ & $7.68^{a}$ & $6.32^{\mathrm{b}}$ & $5.93^{\mathrm{d}}$ & $6.10^{c}$ & 0.119 & 0.061 \\
\hline
\end{tabular}

Means with different letters in same row varied significantly from one another

\section{Conclusion}

Prominent variation appeared in most of the physico-chemical and sensorial characteristics of camel milk produced at different camel habitat zones of Sindh, Pakistan, whereby irrigated plains found dominant followed by coastal mangroves and sandy desert. Regardless, score for sensory attributes of camel milk did not reach at the score rated for buffalo milk; its level was in fact under acceptable limit.

\section{Authors' contributions}


Conceived and designed the experiments: MH Baloch, AH Shah \& H Magsi, Performed the experiments: MH Baloch, Analyzed the data: MH Baloch, MN Rajput \& H Magsi, Contributed materials/ analysis/ tools: ZA Nizamani, Wrote the paper: MH Baloch, AH Shah, MN Rajput \& ZA Nizamani.

\section{References}

1. Farah KO, Nyariki DM, Ngugi RK, Noor IM \& Guliye AY (2004). The Somali and the camel: Ecology, management and economics. Anthropol 6(1): 45-55.

2. Sawaya WN, Khalil JK, Al-Shalhat A \& Al-Mohammad H (1984). Chemical composition and nutritional quality of camel milk. J Food Sci 49: 744-747.

3. El-Batawy MA (1991). Some factors affecting the clotting activity of adult camel rennet. Egypt. J. Dairy Sci. 19: 11730.

4. Abu-Tarboush HM (1996). Comparison of associative growth and proteolytic activity of yoghurt starters in whole milk from camels and cows. J Dairy Sci 79: 366-371.

5. Anonymous (1996). The $A-Z$ of Camels. SPRC. Arab net A-Z of the Arabian camel.htm.

6. Farooqe A (2016). Pakistan Economic Survey (2015-16). Government of Pakistan. Finance Division, Economic Advisor's wing, Islamabad.

7. Khalil IE, Muhammad HA, Hana AA, Inteaz A, \& Taha R (2011). Comparison and characterization of fat and protein composition for camel milk from eight Jordanian locations. Food Chem 127, 282-289.

8. Al-Haj OA, \& Al-Kanhal HA (2010). Compositional, technological and nutritional aspects of dromedary camel milk. Int Dairy J 1-11.

9. Rahli F, Saidi N, \&Kihal M (2013). Evaluation of the factors affecting the variation of the physico-chemical composition of Algerian Camel's raw milk during different seasons. $A d v$ Environ Biol 7(14): 4879-4884.

10. AOAC (2000). Association of Official Analytical Chemists (AOAC). International. Suite 500, 481 North Frederic Avenue, Gaithersburg, Maryland 20877-2417 USA.

11. BSI (1990). Determination of the Nitrogen content of liquid milk. In: Methods for chemical analysis of liquid milk and cream. BSI. 1741, British Standards Institution, London, UK.

12. James CS (1995). Determination of the fat content of dairy products by the Gerber method. Analytical chemistry of Food. Blackie Academic and Professional an imprint of Chapman \& Hall, (Glasgow, UK). pp. 93-95.

13. IDF (1993). International Dairy Federation. Milk: Determination of nonprotein nitrogen content, IDF Standard No. 20B: 4, Parts $1 \&$ 2, IDF, Brussels, (Belgium).

14. Nelson JA \& Trout GM (1981). Judging of dairy products $\left(4^{\text {th }}\right.$ Ed) AVI Publishing Company Inc. Westport, Connecticut. pp. 296-97.

15. Chappalwar AM, Zanjad PN, Pawar VD, \& Machewad GM (2010). An investigation of varying composition and processing conditions on the organoleptical properties of Channa spread. Int J Dairy Tech 63(3): 445-450.

16. Steel RGD, Torrie JH \& Dickie DA ( 1997). Principles and procedures of statistics - a biometric approach. Third edition. McGraw-Hill Publishing Company. Toronto.

17. Abbas S, Ashraf H, Nazir A, \& Sarfraz L (2013). Physico-chemical analysis and composition of camel milk. Intern Research 2(2): 84-98.

18. Hailu Y, Seifu E, \& Yilma Z (2014). Physicochemical properties and consumer acceptability of soft unripened cheese made from camel milk using 
crude extract of ginger (Zingier officinale) as coagulant. African J Food Sci 8(2): 87-91.

19. Isam A, Eissa EA, Yagoub AEA, \&Babiker EE (2011). Physicochemical, microbiological and sensory characteristics of yoghurt produced from camel milk during storage. EJEAF Chemist 10(6): 2305-2313.

20. Walstra P, Wouters TMJ, \& Geurts TJ (2006). Milk components. Dairy Science and Technology. (Ed: $\left.2^{\text {nd }}\right)$. Taylor \& Francis, (USA) pp. 17-108.

21. Khaskheli M, Arain MA, Chaudhary S, Soomro AH, \& Qureshi TA (2005). Physico-chemical quality of camel milk. J Agri Soc Sci 1(2): 164-166.

22. Alkaladi A, Afifi M \& Kamal R (2014). Application of microwave as an alternative home pasteurization method for camel milk; microbiological, physiochemical and biochemical study. Bothalia J 44(4): 301-311.

23. Karim G, \&Gooklani I (1987). Studies on the gross components of camel milk in Turkmen Sahara. 1. Vet. Faculty, Tehran, (Iran) 42: 1.

24. Yoganandi J, Mehta BM, Wadhwani KN, Darji VB, \& Aparnathi KD (2014). Composition of physico-chemical properties of camel milk with cow milk and buffalo milk. J Camel Practice and Res 21(2): 253-258.

25. Spreer E (1998). Milk and Dairy Products Technology. Marcel Dekker, Inc, New York, USA, pp: 38-39.

26. FAO (1982). FAO Animal Production and Health Papers. Camels and Camel Milk. Food Agriculture Organization of the United Nations, Rome.

27. Parragueze $\mathrm{VH}$, Thenot $\mathrm{M}$, Latorre $\mathrm{E}$, Ferrando G, Raggi LA, Camelids C, \& Camelidos C (2003). Milk composition in alpaca (Lama pacos): comparative study in two regions of Chile. Archivos De Zootecnia 431-439.
28. Shuiep ES, El-Zubeir MIE, El-Owni OOA, \& Musa HH (2008). Influence of season and management on composition of raw camel (Camelusdromedarius) milk in Khartoum state, Sudan. Trop. and subtrop. Agro Ecosys 8(1): 101-106.

29. Konuspayeva G, Faye B \& Loiseau G (2009). "The composition of camel milk: a meta- analysis of the literature data." $J$ Food Compo \& Analy 22(2): 95-101.

30. Yadav AK, Kumar R, Priydarshinil L, \& Singh J (2015). Composition and medicinal properties of camel milk: A Review." Asian J Dairy Food Res 34(2): 83-91.

31. Knoess KH, Makhudum AJ, Rafiq M \& Hafeez M (1986). Milk production potential of the dromedary, with special reference to the province of Punjab, Pakistan. World Anim Rev 57: 11-21.

32. Farag SI, \& Kebary KMK (1992). Chemical composition and physical properties of Camel milk and milk fat. Proceed. $5^{\text {th }}$ Egyptian Conference for Dairy Science and Technology. pp. 5767.

33. Al-Kanhal HA., 1993. Goat and camel milk composition and freezing point. Egyptian J Dairy Sci 21: 233-44.

34. Haddadin MSY, Gammoh SI \& Robinson RK (2008). Seasonal variation in the chemical composition of camel milk in Jordan. J Dairy Res 75: 8-12.

35. Larsson RM (1990). Cheese making properties of camel milk. Food Laboratory News 22: 22-25.

36. Gul W, Farooq N, Anees D, Khan U, \&Rehan F (2015). "Camel milk: A Boon to mankind." Int J Res Stud Bio Sci 3(11): 23-29.

37. Knoess KH (1982). Milk production of the dromedary. Pak Vet J 2: 91-8.

38. Ahmed MM (1990). The analysis and quality of camel milk. Index of the thesis accepted for higher degrees by the universities of Great Britain and Ireland 
and the councils for National Academic Awards. 38: 1356.

39. Elamin FM \& Wilcox CJ (1992). Milk composition of Majaheim camels. $J$ Dairy Sci 75(11): 3155-3157.

40. Wolf IV, Bergamini CV, Perotti MC, \& Hynes ER (2013). Sensory and flavor characteristics of milk. Milk and dairy products in human nutrition: Prod Comp and Health 310-337.

41. Sumera C (2001). Study on the Production and quality improvement of yoghurt made from camel milk. M.Sc Thesis submitted to Sindh Agriculture University Tandojam.

42. Al-Kanhal HA (2010). Compositional, technological and nutritional aspects of dromedary camel milk. "Int Dairy J 20(12): 811-821.

43. Tosoe B, Procida G, \& Stefanon B (2002). Determination of volatile compounds in cows' milk using headspace GC-MS. J Dairy Res 69(4): 569-577. 